\title{
'Candidatus Phytoplasma omanense', associated with witches'-broom of Cassia italica (Mill.) Spreng. in Oman
}

Correspondence

Akhtar Jamal Khan ajkhan@squ.edu.om

\author{
Nadiya Abubakar Al-Saady, ${ }^{1}$ Akhtar Jamal Khan, ${ }^{1}$ Alberto Calari, ${ }^{2}$ \\ Ali Masoud Al-Subhi ${ }^{1}$ and Assunta Bertaccini ${ }^{2}$ \\ ${ }^{1}$ Department of Crop Sciences, College of Agricultural \& Marine Sciences, Sultan Qaboos \\ University, PO Box 34, Al-Khod 123, Oman \\ ${ }^{2}$ Department of Agroenvironmental Sciences (DiSTA), Plant Pathology, Alma Mater Studiorum \\ University of Bologna, I-40127 Bologna, Italy
}

\begin{abstract}
Samples from plants of Cassia italica exhibiting typical witches'-broom symptoms (Cassia witches'-broom; CWB) were examined for the presence of plant pathogenic phytoplasmas by PCR amplification using universal phytoplasma primers. All affected plants yielded positive results. RFLP analyses of rRNA gene products indicated that the phytoplasmas detected were different from those described previously. Phylogenetic analysis of $16 \mathrm{~S}$ rRNA gene sequences confirmed that CWB represents a distinct lineage and shares a common ancestor with 'Candidatus Phytoplasma phoenicium'. Molecular comparison revealed that the 16S rRNA gene sequences of the four CWB strains (IM-1, IM-2, IM-3 and IM-4) identified in symptomatic C. italica samples were nearly identical (99.6-100\% similarity). The closest relatives were members of the pigeon pea witches'-broom phytoplasma ribosomal group (16SrIX; 95-97\% sequence similarity). On the basis of unique $16 \mathrm{~S}$ rRNA gene sequences and biological properties, the phytoplasma associated with witches'-broom of $C$. italica in Oman represents a coherent but discrete novel phytoplasma, 'Candidatus Phytoplasma omanense', with GenBank/DDBJ/EMBL accession number EF666051 representing the reference strain.
\end{abstract}

Phytoplasmas are plant-pathogenic, unculturable, wall-less bacteria that are associated with a wide variety of economically important plants (McCoy et al., 1989; Seemüller et al., 2002). In nature, phytoplasmas are transmitted by homopterous insect vectors (Chiykowski \& Sinha, 1989). Traditionally, phytoplasma diseases have been determined on the basis of the host range and characteristic symptoms induced in the plant hosts. Molecular analyses are now used increasingly to identify and differentiate phytoplasmas. Phylogenetic analysis of $16 \mathrm{~S}$ rRNA gene sequence has revealed that phytoplasmas constitute a coherent genus of the Mollicutes (Lee et al., 1998; Seemüller et al., 2002). Currently, they are divided into 18 groups and more than 40 subgroups based upon RFLP analysis of 16S rRNA gene sequences, and a total of 24 members of 'Candidatus Phytoplasma' have been

Abbreviation: CWB, Cassia witches'-broom.

The GenBank/EMBL/DDBJ accession numbers for the sequences of the $16 \mathrm{~S}$ rRNA gene and the 16S-23S rRNA gene spacer region of 'Candidatus Phytoplasma omanense' strains IM-1, IM-2, IM-3 and IM-4 are EF666051-EF666054, respectively.

Details of reference phytoplasmas used in RFLP analysis are available as supplementary material with the online version of this paper. proposed based on 16S rRNA gene phylogeny (IRPCM Phytoplasma/Spiroplasma Working Team - Phytoplasma Taxonomy Group, 2004; Arocha et al., 2005; Valiunas et al., 2006; Lee et al., 2006).

Italian senna [Cassia italica (Mill.) Spreng.], previously known as Cassia obovata (Collad.) or Cassia aschrek (Forsk.), commonly found throughout the Arabian Peninsula, is a wild plant species belonging to the family Fabaceae. It is native to Africa (Sudan) and produces yellow flowers in bunches that become black when opened completely. The seeds are poisonous to animals and plant extracts are used for medical and cosmetic purposes. In this study, we describe a phytoplasma disease of a new host-plant species, C. italica, in Oman. Evidence is also presented to demonstrate that the causal phytoplasmas of C. italica witches'-broom constitute a novel candidate species, for which the name 'Candidatus Phytoplasma omanense' is proposed following the guidelines defined by the International Committee on Systematic Bacteriology (now the International Committee on Systematics of Prokaryotes) for provisional classification of incompletely described micro-organisms (Murray \& Stackebrandt, 1995). 
In 2006, C. italica samples from plants showing witches'broom symptoms (Cassia witches'-broom; CWB) were collected from four separate locations, Manah and AlHamrah in Al-Dakhliya region and Ibra and Al-Qabil in the Al-Sharqiya region of Oman. Symptoms included witches'-broom, stunted growth and yellowing of leaves. A total of 20 diseased plants and 20 symptomless plants (five of each from the four separate locations) were analysed for phytoplasma infection.

For PCR detection, symptomatic and asymptomatic samples were employed for total nucleic acid extraction using an initial enrichment step (Ahrens \& Seemüller, 1992) followed by the CTAB plant DNA extraction procedure of Doyle \& Doyle (1990). PCR was carried out using universal primer pair P1/P7 (Deng \& Hiruki, 1991; Schneider et al., 1995) amplifying a product of about $1800 \mathrm{bp}$ from the $5^{\prime}$ end of the phytoplasma $16 \mathrm{~S}$ ribosomal protein gene to the $5^{\prime}$ region of the $23 \mathrm{~S}$ rRNA gene, including the 16S-23S rRNA spacer region. Nested PCR was then performed by reamplifying $\mathrm{P} 1 / \mathrm{P} 7$ products using primers R16F2/R16R2 (Lee et al., 1995). Products from direct and nested PCR of C. italica samples IM-1 to IM-4 were analysed by single-enzyme digestion with TruI, TaqI, RsaI, HaeIII and HhaI. The resulting RFLP patterns were compared with those of previously characterized strains maintained in the reference phytoplasma collection (Bertaccini et al., 2000). These included KVM (ribosomal subgroup 16SrI-C), SEPT (16SrII-A), LWB (16SrII-B), TBB (16SrII-D), PEP (16SrII-E), GVX (16SrIII-A), CR (16SrIII-B), ULW (16SrV-A), CPS (16SrVI-C), ASHY (16SrVII-A), NAXOS (16SrIX-C), PEY (16SrIX-C), AT (16SrX-A), BVK (16SrXI) and STOL (16SrXII-A) (Fig. 1; see Supplementary Table S1 for details of reference phytoplasmas) (Bertaccini et al., 2000; Khan et al., 2002). Further RFLP comparison was also carried out with previously described phytoplasma strains belonging to ribosomal group 16SrIX (Abou-Jawdah et al., 2003).

To obtain nearly full-length 16S rRNA gene sequences, P1/ P7 products derived from four strains (IM-1, IM-2, IM-3 and IM-4) were purified using PCR Kleen spin columns (Bio-Rad) and cloned into Escherichia coli DH5 $\alpha$-T1 using the TOPO-TA cloning kit (Invitrogen) according to the manufacturer's instructions. Sequencing was performed with dye terminator chemistry (Heiner et al., 1998) using an automated DNA sequencer (ABI Prism 377). Sequence alignments and sequence similarity estimates were obtained using MEGALIGN (Lasergene 6.1, DNASTAR Inc.). Two or three clones of each strain were sequenced. Of the four strains of the CWB phytoplasma, IM-1 was chosen as the reference strain for all molecular analyses.

The 16S rRNA gene sequences of phytoplasmas most closely related to strain IM-1 were compared by putative RFLP analysis. Maps of putative restriction sites (Fig. 2) were constructed using SeqBuilder (Lasergene 6.1).

The 16S rRNA gene sequences of strain IM-1 and 31 published or suggested members of 'Candidatus
Phytoplasma' (IRPCM Phytoplasma/Spiroplasma Working Team - Phytoplasma Taxonomy Group, 2004) were aligned with the Clustal $w$ method using Megalign. Cladistic analyses were performed using PAUP version $4.0 \mathrm{~b} 10$ (Swofford, 2002) on a Power Mac G4. Uninformative characters were excluded from the analysis. A phylogenetic tree was constructed by using heuristic search via random stepwise addition and the tree bisection and reconnection branch-swapping algorithm to find the most parsimonious tree (Gundersen et al., 1994). Acholeplasma laidlawii ATCC $23206^{\mathrm{T}}$ was used as an outgroup taxon to root the tree. Bootstrap analyses (1000 replicates) were performed to estimate the stability of and support for the inferred clades.

All 20 symptomatic plants (five from each of the four locations in the Al-Sharqiya region) tested positive by PCR or nested PCR for phytoplasma infection. No PCR or nested PCR amplification by primer pairs P1/P7 or R16F2/R16R2 was observed when total nucleic acids from 20 asymptomatic plants collected from the same four locations were used as template. RFLP analysis of the PCR-amplified $16 \mathrm{~S}$ rRNA gene sequences from four representative symptomatic C. italica plant samples yielded almost indistinguishable RFLP patterns among four phytoplasma strains (IM-1, IM2, IM-3 and IM-4); the patterns were clearly distinct from all the other phytoplasmas employed as reference strains (data not shown). The $16 \mathrm{~S}$ rRNA gene sequence of strain IM-1 shared $99.6-100 \%$ sequence similarity with those of strains IM-2, IM-3 and IM-4 (data not shown). These phytoplasmas were grouped in a novel taxon related to, but distinct from 'Candidatus Phytoplasma phoenicium' (Verdin et al., 2003). Putative RFLP analysis of the cloned 16S rRNA gene was consistent with results based on RFLP analyses of amplified sequences. Based on putative restriction maps of the 16S rRNA gene obtained using restriction enzymes AluI, HhaI, TaqI and Hinfl, the novel phytoplasma was readily differentiated from its closest relative ' $\mathrm{Ca}$. P. phoenicium' (Fig. 2). Comparative BLAST analysis (Altschul et al., 1997) revealed that the 16S-23S rRNA gene plus spacer sequences (1642 bp) of strain IM-1 shared $97 \%$ similarity with sequences from phytoplasma strains VLL (Vigna little leaf; GenBank accession no. AJ289195), 96\% with ViLL (Y15866), $95 \%$ with Iranian LSP (Lactuca serriola phyllody; DQ889749) and $93 \%$ with 'Ca. P. phoenicium' (AF515637) and PnPWB (pigeon pea witches'-broom; EF186825). The $16 \mathrm{~S}$ rRNA gene sequence of strain IM-1 (1424 bp) shared $97 \%$ similarity with ViLL (GenBank accession no. Y15866) and VLL (AJ289195), $96 \%$ with 'Ca. P. phoenicium' (AF515636) and 95\% with Iranian LSP (DQ889749) and PnPWB (AF248957). The spacer region (16S-23S; 77 bp) of strain IM-1 was highly conserved, exhibiting 90 and $86 \%$ sequence similarity with those of strains ViLL (GenBank accession no. Y15866) and 'Ca. P. fragariae' (EF015582), respectively.

Phylogenetic analysis using nearly full-length $16 \mathrm{~S}$ rRNA gene sequences of strain IM-1 and 31 published or suggested members of ' $\mathrm{Ca}$. Phytoplasma' (IRPCM Phytoplasma/Spiroplasma Working Team - Phytoplasma 


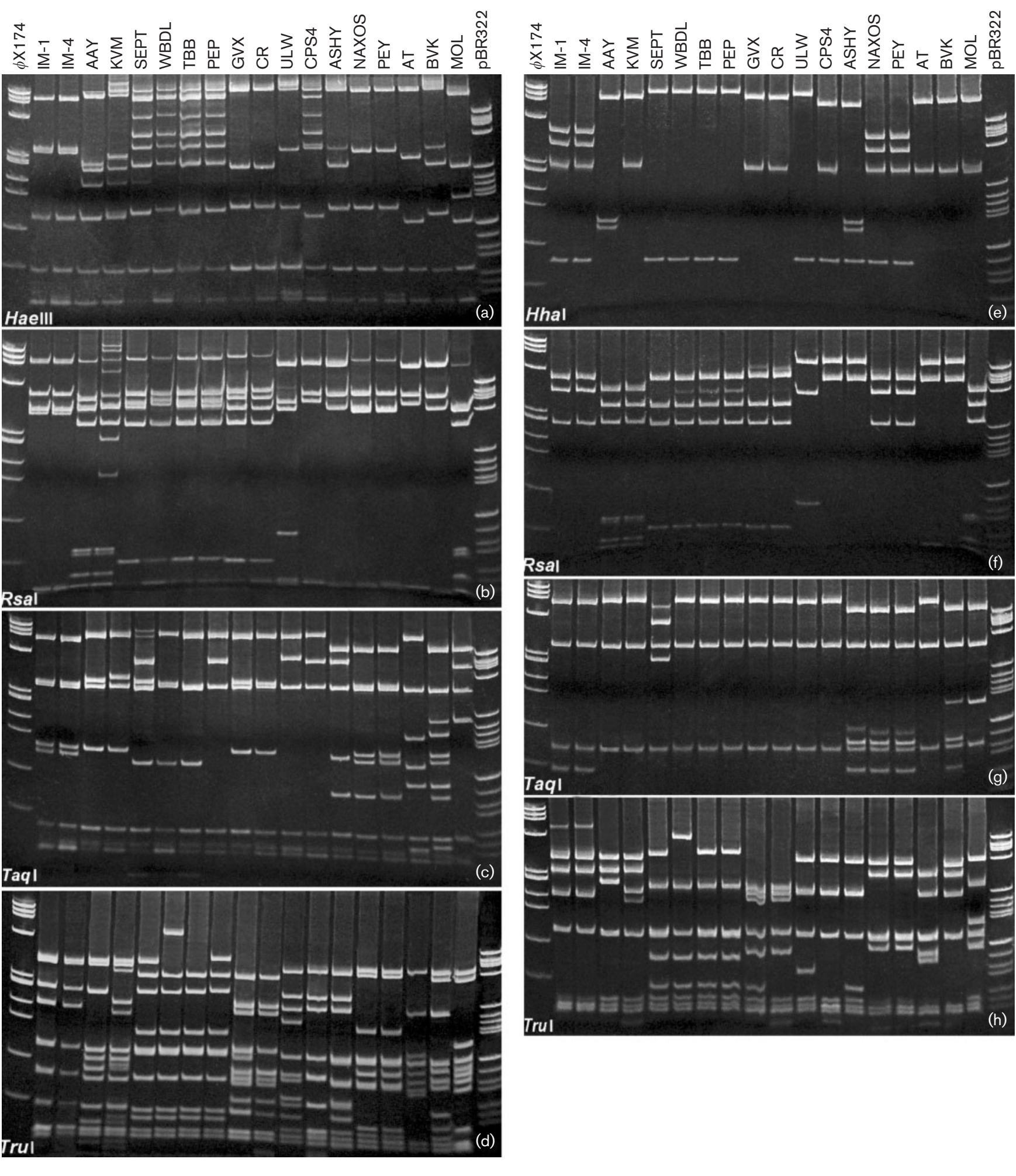

Fig. 1. RFLP profiles of $1642 \mathrm{bp}(\mathrm{a}-\mathrm{d})$ and $1200 \mathrm{bp}(\mathrm{e}-\mathrm{h})$ products amplified by direct PCR using primer pair $\mathrm{P} 1 / \mathrm{P} 7$ and by nested PCR with primers R16F2/R16R2 from representative reference phytoplasmas and from strains IM-1 and IM-4 detected in C. italica in Oman. A list of the reference strains used for comparison is provided in the text. PCR products were digested separately with restriction enzymes (indicated in the figures) and separated by electrophoresis through $5 \%$ polyacrylamide gels. Markers: $\phi \mathrm{X} 174$, a $\phi \mathrm{X} 174$ Haell digest [fragment sizes (bp) from top to bottom: 1353, 1078, 872, 603, 310, 281, 234, 194, 118 and 72]; pBR322, a pBR322 BsuRI digest (587, 540, 502, 458, 434, 267, 234, 213, 192, 184, 124, 123, 104, 89, 80, 64,57 and 51). 


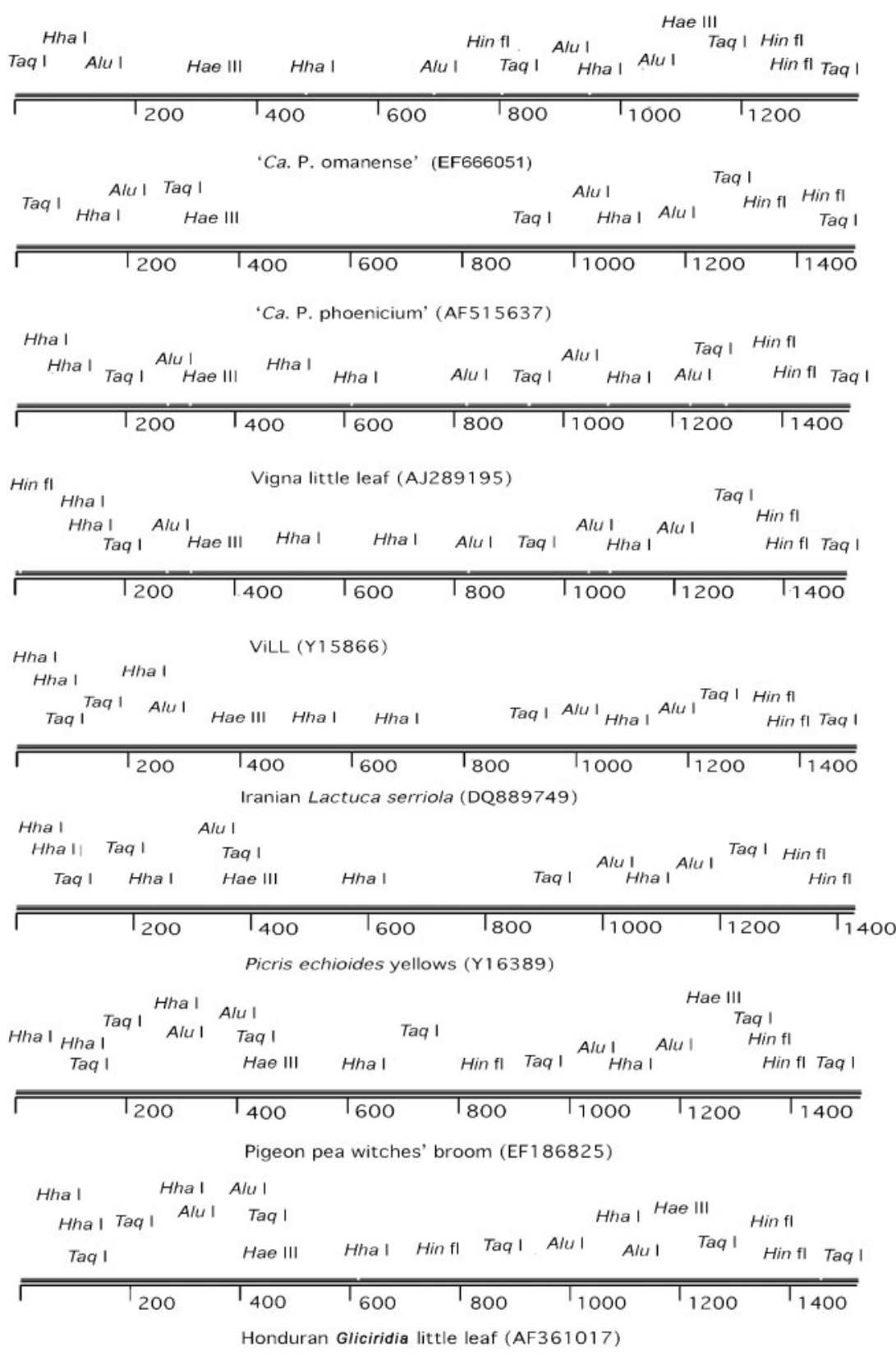

Fig. 2. Comparative analysis of putative restriction sites in 16S rRNA gene sequences of 'Candidatus Phytoplasma' candidate species and phytoplasma strains most closely related to 'Ca. P. omanense'. Sequences were obtained from GenBank. All sequences are 16S rRNA gene sequences of about $1500 \mathrm{bp}$.
Taxonomy Group, 2004) yielded four equally parsimonious trees; one of these trees is presented in Fig. 3. Based on actual and putative RFLP analysis and on phylogenetic analyses of $16 \mathrm{~S}$ rRNA gene sequences, the CWB-associated phytoplasmas belong to a new RFLP group, which we designate 16SrXIX. Sequence similarity comparisons determined that the $16 \mathrm{~S}$ rRNA gene sequence of the CWB phytoplasma shares no more than $94 \%$ similarity with those of all previously described members of ' $\mathrm{Ca}$. Phytoplasma'. Therefore, according to guidelines for assigning incompletely described prokaryotes to the provisional status of Candidatus (Murray \& Stackebrandt, 1995), we propose that the phytoplasma associated with witches'-broom disease of C. italica in Oman be designated 'Candidatus Phytoplasma omanense'.

\section{Description of 'Candidatus Phytoplasma omanense'}

'Candidatus Phytoplasma omanense' [N.L. neut. adj. omanense of or pertaining to Oman (Mollicutes)] NC; NA; O, wall-less; NAS (GenBank accession number EF666051), oligonucleotide sequences of unique regions of the 16S rRNA gene are 5' -AAAAAACAGT-3' (467-474), 5' -TTGC-3' (642-645), 5'-GTTAAAG-3' (853-861), 5' TAATT-3' (1010-1014) and 5'-AAATT-3' (1052-1056); P (Cassia italica, phloem); M]. As described previously (IRPCM Phytoplasma/Spiroplasma Working Team Phytoplasma Taxonomy Group, 2004), specific nucleotide signatures $\mathrm{A}$ at position 242, $\mathrm{T}$ at position 286 and $\mathrm{T}$ at position 1247 that are characteristic of ' $\mathrm{Ca}$. Phytoplasma' 


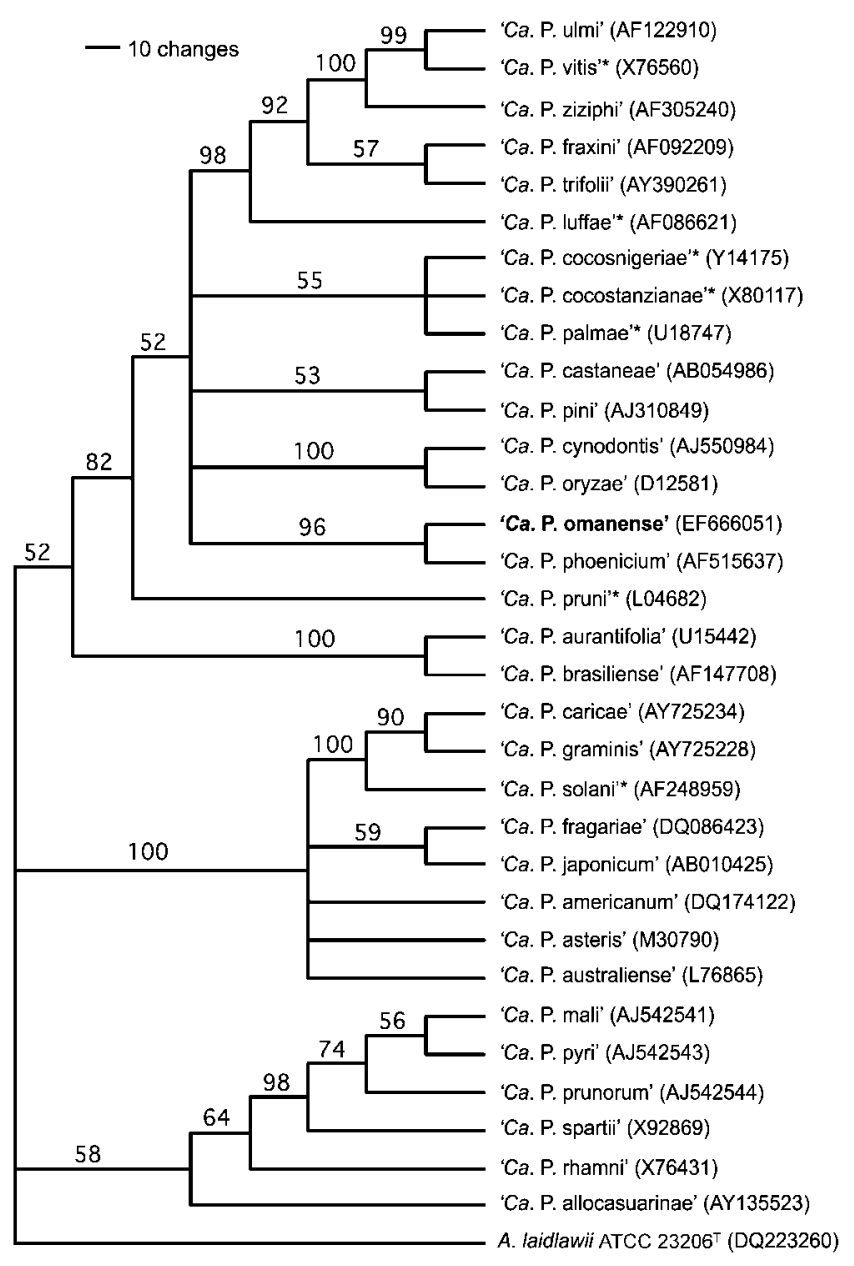

Fig. 3. Phylogenetic tree constructed by parsimony analysis of nearly full-length $16 \mathrm{~S}$ rRNA gene sequences from previously described or suggested members of 'Ca. Phytoplasma' and the novel 'Ca. P. omanense' phytoplasma strain IM-1. Names indicated by asterisks are Candidatus names proposed at the Tenth International Congress of the International Organization of Mycoplasmology held in 1994 in Bordeaux, France, but not yet formally described; they are reported here as incidental citations which do not constitute prior citations, according to Rule $28 \mathrm{~b}$ of the Bacteriological Code (Lapage et al., 1992). A. laidlawii ATCC $23206^{\top}$ was used as an outgroup taxon to root the tree. Branch lengths are proportional to the number of inferred character state transformations. Bootstrap values $>50 \%$ (measures of support for the inferred subclades) are shown on branches. GenBank accession numbers are given in parentheses. Bar, 10 inferred character state changes.

are present in the sequence of ' $\mathrm{Ca}$. P. omanense' strains IM-1, IM-2, IM-3 and IM-4. IM-1 is the reference strain, with GenBank/EMBL/DDBJ accession number EF666051. DNA samples from these strains are available from the authors.

\section{References}

Abou-Jawdah, Y., Karakashian, A., Sobh, H., Martini, M. \& Lee, I.-M. (2003). An epidemic of almond witches'-broom in Lebanon: classification and phylogenetic relationships of the associated phytoplasmas. Plant Dis 86, 477-484.

Ahrens, U. \& Seemüller, E. (1992). Detection of DNA of plant pathogenic mycoplasma-like organisms by a polymerase chain reaction that amplifies a sequence of the 16S rRNA gene. Phytopathology 82, 828-832.

Altschul, S. F., Madden, T. L., Schäffer, A. A., Zhang, J., Zhang, Z., Miller, W. \& Lipman, D. J. (1997). Gapped BLAST and PSI-BLAST: a new generation of protein database search programs. Nucleic Acids Res 25, 3389-3402.

Arocha, Y., López, M., Piñol, B., Fernández, M., Picornell, B., Almeida, R., Palenzuela, I., Wilson, M. R. \& Jones, P. (2005). 'Candidatus Phytoplasma graminis' and 'Candidatus Phytoplasma caricae', two novel phytoplasmas associated with diseases of sugarcane, weeds and papaya in Cuba. Int J Syst Evol Microbiol 55, 2451-2463.

Bertaccini, A., Carraro, L., Davies, D., Laimer da Camara Machado, M., Martini, M., Paltrinieri, S. \& Seemüller, E. (2000). Micropropagation of a collection of phytoplasma strains in periwinkle and other host plants. In Proceedings of the 13th International Congress of the International Organization for Mycoplasmology, Fukuoka, Japan, 14-19 July 2000, p. 101.

Chiykowski, I. N. \& Sinha, R. C. (1989). Differentiation of MLO disease by means of symptomatology and vector transmission. Zentralbl Bakteriol Hyg 20 (Suppl.), 280-287.

Deng, S. \& Hiruki, C. (1991). Amplification of $16 \mathrm{~S}$ rRNA genes from culturable and nonculturable mollicutes. J Microbiol Methods 14, 53-61.

Doyle, J. J. \& Doyle, J. L. (1990). Isolation of plant DNA from fresh tissue. Focus 12, 13-15.

Gundersen, D. E., Lee, I.-M., Rehner, S. A., Davis, R. E. \& Kingsbury, D. T. (1994). Phylogeny of mycoplasma-like organisms (phytoplasmas): a basis for their classification. J Bacteriol 176, 5244-5254.

Heiner, C. R., Hunkapillar, K. L., Chen, S. M., Glass, J. I. \& Chen, E. Y. (1998). Sequencing multimegabase-template DNA with Big Dye Terminator Chemistry. Genome Res 8, 557-561.

IRPCM Phytoplasma/Spiroplasma Working Team - Phytoplasma Taxonomy Group (2004). 'Candidatus Phytoplasma', a taxon for the wall-less, non-helical prokaryotes that colonize plant phloem and insects. Int J Syst Evol Microbiol 54, 1243-1255.

Khan, A. J., Botti, S., Al-Subhi, A. M., Gundersen-Rindal, D. E. \& Bertaccini, A. (2002). Molecular identification of a new phytoplasma strain associated with alfalfa witches'-broom in Oman. Phytopathology 92, 1038-1047.

Lapage, S. P., Sneath, P. H. A., Lessel, E. F., Skerman, V. B. D., Seeliger, H. P. R. \& Clark, W. A. (editors) (1992). International Code of Nomenclature of Bacteria (1990 Revision). Bacteriological Code. Washington, DC: American Society for Microbiology.

Lee, I.-M., Bertaccini, A., Vibio, M. \& Gundersen, D. E. (1995). Detection of multiple phytoplasmas in perennial fruit trees with decline symptoms in Italy. Phytopathology 85, 728-735.

Lee, I.-M., Gundersen-Rindal, D. E., Davis, R. E. \& Bartoszyk, I. M. (1998). Revised classification scheme of phytoplasmas based on RFLP analyses of $16 \mathrm{~S}$ rRNA and ribosomal protein gene sequences. Int J Syst Bacteriol 48, 1153-1169.

Lee, I.-M., Bottner, K. D., Secor, G. \& Rivera-Varas, V. (2006). 'Candidatus Phytoplasma americanum', a phytoplasma associated 
with a potato purple top wilt disease complex. Int J Syst Evol Microbiol 56, 1593-1597.

McCoy, R. E., Caudwell, A., Chang, C. J., Chen, T. A., Chikowsky, I. N., Cousin, M. T., Dale de Leeuw, G. T. N., Golino, D. A., Hackett, K. J. \& other authors (1989). Plant diseases associate with mycoplasma-like organisms. In The Mycoplasmas, vol. 5, pp. 545-560. Edited by R. F. Whitcomb \& J. G. Tully. New York: Academic Press.

Murray, R. G. E. \& Stackebrandt, E. (1995). Taxonomic note: implementation of the provisional status Candidatus for incompletely described prokaryotes. Int J Syst Bacteriol 45, 186-187.

Schneider, B., Seemüller, E., Smart, C. D. \& Kirkpatrick, B. C. (1995). Phylogenetic classification of plant pathogenic mycoplasma-like organisms or phytoplasmas. In Molecular and Diagnostic Procedures in Mycoplasmology, vol. 2, pp. 369-380. Edited by S. Razin \& J. G. Tully. San Diego: Academic Press.
Seemüller, E., Garnier, M. \& Schneider, B. (2002). Mycoplasma of plants and insects. In Molecular Biology and Pathology of Mycoplasmas, pp. 91-116. Edited by S. Razin \& R. Hermann. London: Kluwer Academic/Plenum Publishers.

Swofford, D. L. (2002). PAUP*: Phylogenetic analysis using parsimony ( ${ }^{*}$ and other methods), version 4. Sunderland, MA: Sinauer Associates.

Valiunas, D., Staniulis, J. \& Davis, R. E. (2006). 'Candidatus Phytoplasma fragariae', a novel phytoplasma taxon discovered in yellows diseased strawberry, Fragaria $\times$ ananassa. Int $J$ Syst Evol Microbiol 56, 277-281.

Verdin, E., Salar, P., Danet, J. L., Choueiri, E., Jreijiri, F., El Zammar, S., Gelie, B., Bové, J. M. \& Garnier, M. (2003). 'Candidatus Phytoplasma phoenicium' sp. nov., a novel phytoplasma associated with an emerging lethal disease of almond trees in Lebanon and Iran. Int $J$ Syst Evol Microbiol 53, 833-838. 